\title{
MINERVINO DE OLIVEIRA: UM NEGRO COMUNISTA DISPUTA A PRESIDÊNCIA DO BRASIL
}

Petrônio Domingues

é doutor em História pela Universidade de São Paulo e professor da Universidade Federal de Sergipe (UFS). São Cristóvão, SE, Brasil.E-mail:<pjdomingues@yahoo.com.br>

http://dx.doi.org/10.1590/0102-013051/101

All Negroes are aware of the mass of lies on which the prejudice is built, of the propaganda which is designed to cover the naked economic exploitation.

JAMES, C. L. R.

No segundo semestre de 1929 a sucessão presidencial foi o assunto da agenda nacional que mais despertou a atenção da população brasileira. A imprensa produziu inúmeras matérias, reportagens e artigos para informar, debater e especular sobre as eleições presidenciais, marcadas para 30 de março de 1930. O presidente da República, o representante da oligarquia paulista Washington Luís, declinou do apoio ao seu sucessor "natural", Antônio Carlos de Andrade, governador de Minas Gerais, preferindo indicar Júlio Prestes, governador de São Paulo. Washington Luís descumpriu a "política dos estados" - na qual as oligarquias dos principais estados, sobretudo de São Paulo e Minas Gerais, definiam o candidato presidencial a cada sucessão e se revezavam no poder da República -, o que parte da historiografia chamou de "política do café com leite”, já que São 
Paulo e Minas Gerais se tratavam dos maiores produtores de café e leite do país, respectivamente. ${ }^{1}$ Em julho de 1929, ele declarou que Júlio Prestes catalisaria o arco de alianças dos Partidos Republicanos, e não escondeu que o aparato político do domínio oligárquico de dezessete dos vinte estados do Brasil seria colocado a serviço de seu candidato. O preterido Antônio Carlos, jogando com a insatisfação das demais facções oligárquicas, articulou uma chapa de oposição, cujo cabeça escolhido foi Getúlio Vargas, governador do Rio Grande do Sul. Formou-se então a Aliança Liberal, aglutinando as "máquinas políticas" de três grandes oligarquias dissidentes (Minas Gerais, Rio Grande do Sul e Paraíba), que recebeu ainda o apoio do Partido Democrático de São Paulo. O programa da Aliança Liberal não se diferenciava dos apresentados pelas oposições oligárquicas em disputas anteriores, a não ser por uma ênfase maior em reformas políticas e medidas de regulamentação do trabalho, almeja14 das pela classe operária há longa data.

O Partido Comunista do Brasil (PCB) não confiava em Júlio Prestes, candidato oficial à presidência, e estava certo que uma eventual vitória dele nas urnas se daria com o apoio do imperialismo inglês e por meio dos velhos métodos políticos das oligarquias. Os comunistas também não depositavam esperança na Aliança Liberal e em seu candidato Getúlio Vargas, considerado um representante do

\footnotetext{
1 A "política dos estados" ou do "café com leite" não deve ser vista por uma perspectiva monolítica. Como Hebe Mattos argumenta, a historiografia mais recente sobre as sucessões presidenciais, "ainda que corroborando o funcionamento da política dos estados", ressaltou um "nível maior de incerteza e um número, ainda que restrito, porém mais diversificado, de atores privilegiados". Sem dúvida, o "caráter oligárquico do arranjo político então engendrado, fraudando e desmoralizando as eleições, conforme foi amplamente denunciado na própria época, impôs-se como 'regra do jogo'. Mas a unidade de objetivos entre as oligarquias de São Paulo e Minas Gerais, em torno dos interesses cafeeiros, era apenas relativa. PRP e PRM nem sempre estiveram juntos ou de acordo. Pelo menos os chamados estados de segunda grandeza mantiveram presença importante nas negociações políticas das sucessões presidenciais do período" (Mattos, 2012, p. 104). Sobre o assunto, ver também Viscardi (2012).
} 
imperialismo norte-americano. Para a libertação das "massas proletárias e pequeno-burguesas" - diziam as lideranças do PCB - era necessário um programa que incluísse dois pontos essenciais: "o confisco sem indenização das terras dos grandes proprietários do campo, para a entrega dessas terras aos camponeses pobres; e a luta feroz contra o imperialismo internacional". Nem o "situacionista" Júlio Prestes nem o “oposicionista” Getúlio Vargas - concluíam - poderiam cumprir um programa desta natureza, pois ambas as candidaturas eram "burguesas"; avalizadas por grupos oligárquicos e imperialistas. Da perspectiva operária, elas nada significavam, pois jamais defenderiam os interesses da classe. Até mesmo os pontos da plataforma da Aliança Liberal relativos aos direitos trabalhistas não passariam de manobra retórica, destinada a atrair o voto dos operários (A Significação..., 1930; Consultando..., 1929; Realiza-se..., 1929).

A partir dessa avaliação, os comunistas decidiram indicar Minervino de Oliveira como candidato à presidente da República, pelo Bloco Operário e Camponês (BOC). Sua candidatura procurava, assim, expressar uma alternativa vinculada aos interesses da classe trabalhadora. Mas quem era esse sujeito? Como se deu sua iniciação, maturidade e ascensão nos movimentos sociais? Como transcorreu sua campanha político-eleitoral, em termos de programa, mobilização, reveses e debates - se é que houve - em torno da chamada "questão negra"? A finalidade deste artigo é apresentar breves notas acerca do referido personagem e, sobretudo, reconstituir aspectos de sua carreira política e campanha eleitoral entre o final de 1929 e o primeiro trimestre de 1930.

\section{Aderindo ao "credo vermelho"}

Minervino de Oliveira nasceu no Rio de Janeiro em 1891, três anos após a abolição da escravidão no Brasil. De família humilde - filho de José de Oliveira e Augusta Laura 
de Oliveira -, pouco se conhece de seus pais. ${ }^{2}$ Sabe-se, no entanto, que Minervino tinha origem negra e começou a trabalhar cedo - aos 10 anos de idade. Foi aprendiz de tecelão na fábrica São João, depois, labutou no comércio e em fábricas de vidro e móveis. Aos catorze anos, iniciou-se no ofício de marmorista. Dedicou-se, ainda, a atividades temporárias: foi lavrador, carvoeiro e empregado da Light. Retornou ao ramo da marmoraria e, talvez pensando no futuro, resolveu fazer carreira. ${ }^{3}$

Com o tempo, indignou-se com as altas jornadas de trabalho, os baixos salários, os abusos das chefias, enfim, com as condições de trabalho adversas. Por volta de 1911, com vinte anos de idade, engajou-se na militância sindical, tendo em vista pugnar pelos direitos dos trabalhadores. Entrou para o Centro dos Operários Marmoristas e ocupou o cargo de secretário várias vezes. ${ }^{4}$ Impetuoso, participou de campanhas salariais, fomentou greves e articulou diversas mobilizações sindicais ao longo da década (A Gréve..., 1919; O "Lock-Out"..., 1918; Terminou..., 1918; Terminou..., 1919), o que o levou a "amargar no fundo das masmorras policiais". Não sucumbiu. Tornou-se uma liderança dos trabalhadores conhecida e respeitada, colaborou com a imprensa operária, escrevendo para A Voz do Trabalhador (Batalha, 2015, p. 83), Spartacus, Voz do Povo, entre outras publicações. No

2 O pintor modernista Di Cavalcanti relata em livro de memórias que, numa reunião de célula no "Partido Comunista" em 1928, ele se deparou com Minervino de Oliveira e se lembrou dele e de sua mãe da época da infância: "Enquanto [Octavio] Brandão falava, eu fixava os olhos na figura de Minervino de Oliveira sentado à minha frente. Reconheci-o: era ele o moleque Minervino, filho de Sinhá Inácia, lavadeira de minha avó Henriqueta, companheiro de meus primos mais velhos nas estripulias aquáticas da Ponta do Caju, local escolhido para os banhos de mar da minha família. O magro, alto Minervino ali estava. Via-o com novos olhos sentindo uma íntima satisfação" (Di Cavalcanti, 1964, pp. 37-38).

3 Os dados biográficos de Minervino de Oliveira foram extraídos de jornais da época. (Minervino..., 1954; Minervino..., [192-?]; Octavio..., 1928).

4 A primeira notícia apurada na imprensa, relacionada à militância sindical de Minervino de Oliveira, remonta a 1913 (Columna..., 1913). 
3ํㅡㄹ Congresso Operário Brasileiro - certame realizado no Rio de Janeiro em agosto de 1920, reunindo representantes sindicais de várias partes do Brasil - foi um dos delegados. ${ }^{5}$ Anos mais tarde, filiou-se ao Partido Comunista do Brasil e passou a colaborar com A Classe Operária, jornal oficial do partido.

\section{A vanguarda da revolução}

O Partido Comunista do Brasil nasceu num Congresso iniciado no Rio de Janeiro e concluído em Niterói, entre 25 e 27 de março de 1922. Reuniu nove delegados, representando cerca de 130 ativistas espalhados pelas cidades de Porto Alegre, Recife, Juiz de Fora, Cruzeiro, Niterói, São Paulo, Santos e, especialmente, Rio de Janeiro. Surgiu após anos de discussão no seio do movimento operário brasileiro sobre um projeto de revolução. De acordo com seus estatutos, a agremiação tinha por finalidade "promover o entendimento, a ação internacional dos trabalhadores e a organização política do proletariado em partido de classe, para a conquista do poder e consequente transformação política e econômica da sociedade capitalista em sociedade comunista" (Dulles, 1977, p. 147). Sua principal inspiração era a experiência da Rússia relacionada ao triunfo da Revolução Bolchevique, fato que causou grande euforia e entusiasmo entre os trabalhadores de várias partes do mundo.

Em maio de 1923, o PCB contabilizava por volta de "300 membros, conquistados em condições muitos difíceis”. Um ano depois, tornou-se partido-membro da Internacional Comunista sediada em Moscou e, a partir dali, incorporou as diretrizes da "Revolução Mundial" ao lado de outros Partidos Comunistas na América Latina. À luz da realidade brasileira, os comunistas formularam sua principal tese

\footnotetext{
5 Sobre a história do movimento operário do período em que Minervino de Oliveira se transformou em liderança sindical, ver Fausto (1977), Maram (1979), Pinheiro e Hall (1979), Carone (1979), Batalha (2000, 2008), Mattos (2002) e Gomes (2005).
} 
política pautando-se numa concepção dualista do desenvolvimento nacional - "agrarismo versus industrialismo". $\mathrm{O}$ Brasil era caracterizado como um país atrasado, de "capitalismo agrário semicolonial”, por isso entendiam que o processo revolucionário aqui se daria por etapas preparatórias e sucessivas. A transição à "ditadura do proletariado" só seria possível por intermédio de, inicialmente, uma revolução democrática "pequeno-burguesa" que, fruto da aliança dos trabalhadores com a "pequena burguesia", 6 impulsionaria o desenvolvimento do capitalismo industrial moderno. Depois de vitoriosa a etapa de transformação "pequeno-burguesa”, seguir-se-ia a revolução socialista, comandada pelo PCB (Carone, 1982; Chilcote, 1982; Del Roio, 2007; Pereira, 1976, p. 78; Pinheiro, 1991; Rodrigues, 1981, pp. 361-443; Segatto, 1989, pp. 17-43; Vianna, 2007, pp. 333-335).

$\mathrm{Na}$ fase inicial, a agremiação realizou um trabalho de estruturação, oferecendo cursos de formação política e editando material informativo sobre seu papel, suas atividades e seus fins; mas, em virtude da eclosão da revolta dos "tenentes" - a revolta do Forte de Copacabana, em 5 de julho de 1922 -, o presidente Arthur Bernardes decretou estado de sítio, desencadeando uma escalada persecutória, tanto ao movimento tenentista quanto ao movimento operário, o PCB teve sua sede invadida e fechada pelos agentes da chamada "polícia política", sendo colocado na ilegalidade meses depois de seu nascedouro.

\footnotetext{
6 O PCB usava o termo "pequena burguesia" para se referir aos setores médios urbanos da população, cuja vanguarda seria representada pelos chamados "tenentes" - jovens oficiais do Exército que formaram um movimento político-militar de oposição governo e protagonizaram a revolta do Forte de Copacabana, em 1922, a Revolução de 1924, em São Paulo, e a Coluna Prestes, a partir de 1925. O movimento tenentista nunca teve uma unidade política nem chegou a assumir um programa definido, embora lutasse contra as oligarquias e por medidas saneadoras da vida pública, sem maiores transformações na estrutura socioeconômica do país. Postulava também uma tática de golpes militares à revelia da mobilização popular (Borges, 1992).
} 
Não é de estranhar que isso tenha acontecido, o emergente movimento dos trabalhadores, as greves, as manifestações de rua, a Revolução Russa, o Partido Comunista, enfim, o espectro da "revolução" gerava um clima de medo e apreensão nas autoridades brasileiras. Sem postergar, estas instituíram novos métodos de prevenção e repressão às lutas sociais (Mattos et al., 2004). As démarches teriam surtido efeito, pelo menos é o que sugere a entrevista de Minervino de Oliveira ao jornal $A$ Critica, na qual acusava o governo de Arthur Bernardes de quatro anos de "deportações de operários, perseguições a trabalhadores conscientes, espancamentos, 'suicídios' nas prisões, etc.”. "Foi Bernardes”, dizia o líder sindical, "quem mandou para a Clevelândia centenas de operários, onde encontravam a sua desgraça, morrendo centenas deles em consequências dos maus tratos" (Bernardes..., 1928).

No que tange ao PCB, tudo se complicou naquele contexto de "caça às bruxas", entretanto, o partido não desapareceu nem cessou suas atividades. Foi na ilegalidade que Minervino de Oliveira a ele aderiu; talvez tenha se convencido, a partir de sua experiência no movimento operário e contato com a literatura marxista-leninista, que havia diferenças conceituais entre sindicato e partido revolucionário. Se o primeiro era concebido como uma organização da classe trabalhadora, formada para defender seus interesses específicos na luta contra a exploração patronal, o segundo também era considerado uma organização ligada à classe trabalhadora, porém criada com o fito de esposar um projeto político revolucionário para o conjunto da população, calcado na luta pela tomada do poder. Enquanto os sindicatos eram vistos como organizações de massa, os partidos eram tidos como organizações de vanguarda, compostos, em geral, por aqueles trabalhadores que compartilhavam uma identidade 
ideológica expressa no programa do partido. ${ }^{7}$ Minervino de Oliveira abraçou de "corpo e alma" o programa do PCB, em sua opinião, os problemas sociais da nação só seriam resolvidos por uma transformação radical do regime. Tal transformação passaria primeiro pela instalação de uma "democracia pequeno-burguesa" e esta, numa segunda etapa, desembocaria em uma "democracia proletária".

\section{A "frente única"}

Em 1926, houve eleições para presidente da República, o escolhido para suceder Arthur Bernardes foi Washington Luís, mais um representante do domínio oligárquico no Brasil. Quando tomou posse, o novo presidente decretou o fim do estado de sítio e restabeleceu a vigência das garantias constitucionais. Aproveitando a conjuntura de abertura democrática, o PCB conquistou a legalidade, valeu-se de $A$ Nação, um jornal diário que levava seu programa a uma grande parcela da população carioca e, no início de 1927, criou o Bloco Operario, coligação cujo escopo era unificar os indivíduos e organismos políticos que comungavam de afinidade mínima de interesses, tendo em vista à disputa eleitoral. Inspirado na política de "frente única", aprovada no III Congresso da Internacional Comunista, o Bloco Operario aglutinava diferentes pessoas e agrupamentos que se proclamavam representantes e defensores dos trabalhadores. Seu programa de treze pontos falava, entre outras coisas, em "soluções imediatas dos mais graves e prementes problemas do proletariado”, legislação social, reconhecimento da União Soviética, combate ao imperialismo, liberdades políticas (direito à associação, à reunião, ao pensamento e à palavra), novo sistema eleitoral (voto secreto e obrigatório), 7 Sobre o conceito de sindicato e partido no pensamento marxista-leninista, ver a
obra de referência de Lênin $(1975[1902])$. 
acesso à habitação e educação, direitos dos militares de baixa patente, dos imigrantes, das mulheres; entretanto, omitia-se em relação aos direitos de outros grupos específicos, como os negros e os indígenas.

De toda sorte, o Bloco Operario propunha um repertório de reivindicações classistas, candidaturas operárias e buscava constituir na pequena burguesia uma interlocutora privilegiada (Karepovs, 2006, p. 56; Pereira, 1976, pp. 116-122; Zaidan Filho, 1989, p. 23). No plano sindical, os comunistas envidaram esforços na organização do Congresso Sindical Regional, ocorrido no Rio de Janeiro em abril de 1927, quando criaram a Federação Sindical Regional do Rio de Janeiro, da qual Minervino de Oliveira foi secretário-geral da Comissão Executiva. A política sindical do PCB começou a vicejar. Sua campanha pela sindicalização e a construção de uma "frente única proletária” contribuíram para a formação de dirigentes partidários organicamente ligados ao movimento dos trabalhadores (Batalha, 2000, p. 62; Del Roio, 2007, p. 236).

Com efeito, houve uma guinada na conjuntura política do país. Progressivamente Washington Luís adotou medidas repressivas contra os movimentos sociais, sob o pretexto de combater os atos contrários à ordem e segurança públicas, o que culminou na aprovação da "Lei Celerada", em agosto de 1927. Tido como uma organização "subversiva", o PCB foi fechado novamente, abortando parte do trabalho realizado no curto período de vida legal. Ainda que mergulhada na clandestinidade, a organização procurou se rearticular e investir na política de aliança com a "pequena burguesia ao seu limite, o que a fez travar relações mais próximas com alguns setores de oposição ao regime e ganhar espaços de intervenção e exposição de suas ideias" (Karepovs, 2006, p. 76) ${ }^{8}$ O PCB decidiu então

\footnotetext{
8 Sobre a aliança do PCB com políticos da "pequena burguesia", com seus significados e desdobramentos, nesse período, ver Lima (1931, p. 120).
} 
revitalizar o Bloco Operario, a fim de que este pudesse ser utilizado como frontispício para a ligação do partido com as massas.

Sobrepondo a estrutura de uma entidade de caráter eleitoral legal à de uma organização político-partidária ilegal, o Bloco Operario assumiu muitas das incumbências que seriam próprias do $\mathrm{PCB}$ e, a partir daquele instante, alterou seu nome para Bloco Operario e Camponez (BOC), como maneira de ampliar seu raio de ação também abrangendo os trabalhadores rurais, o que nunca se concretizou. De todo modo, foram abertas seções em importantes centros urbanos, sendo os de São Paulo, Santos, Distrito Federal, Niterói, Petrópolis, Recife, Juiz de Fora e Ribeirão Preto os que mais se destacaram (Dias, 1977, p. 155; Zaidan Filho, 1989, pp. 54-55). Nas eleições de outubro de 1928, o BOC lançou dois candidatos à intendente (cargo correspondente hoje ao de vereador) no Conselho Municipal (atual Câmara de Vereadores) do Distrito Federal: Octavio Brandão (pelo $1^{\circ}$ Distrito) e Minervino de Oliveira (pelo $2^{\circ}$ Distrito), que, na época, colaborava com A Nação, era redator da Voz do Marmorista e dirigente da Federação Sindical Regional do Rio de Janeiro.

Segundo o jornal A Classe Operaria, Minervino era "um dos antigos militantes do proletariado do Rio de Janeiro. Sempre na vanguarda, sempre na luta contra os exploradores! Conhecendo a fundo a vida dos trabalhadores, operário desde a mais tenra idade, organizador e jornalista proletário, merece a simpatia do eleitorado consciente" (Octavio..., 1928). Era a primeira vez que os comunistas brasileiros disputavam cargos eletivos do Poder Legislativo.

\section{A bandeira vermelha com a foice e o martelo ocupa 0 parlamento}

É importante assinalar que os comunistas viam as casas legislativas como instituições biombos para os interesses da 
burguesia e não acreditavam na possiblidade de chegar ao poder pela via eleitoral. Apesar disso, atribuíam importância à militância no campo político-institucional, tanto as campanhas eleitorais como a atuação no legislativo deviam ocorrer com o intuito de mobilizar e conscientizar as massas da necessidade da "revolução proletária". Se Minervino for eleito prognosticava A Classe Operaria por ocasião do lançamento da sua candidatura -, "saberá corresponder às expectativas dos trabalhadores. Será, no Conselho Municipal, uma alavanca da luta de classes, um organizador e um educador das massas laboriosas" (Octavio..., 1928). As eleições eram vistas, assim, como espaço para agitação e propaganda, junto às massas, do programa "revolucionário" (Realiza-se..., 1929).

Os comunistas estavam dispostos a utilizar de todos os meios possíveis de combate para se alcançar o objetivo final (As eleições..., 1928). Na base de poucos recursos e muito voluntarismo, a campanha de Minervino de Oliveira priorizou a interação direta com os trabalhadores, por meio de visitas à porta de fábricas, panfletagens, debates e festivais. Nessas ocasiões - relata Octavio Brandão - ele "mostrava as mãos, aquelas mãos cheias de calos, aqueles calos tremendos" e dizia: "Eu sou operário e aqui está a prova'. Pronto... virava a cabeça dos operários". Outro expediente de campanha bastante empregado pelos candidatos do BOC foi o comício:

Fizemos uma lista das grandes empresas do Rio de Janeiro. E, uma por uma, na hora do almoço, ou às quatro horas fomos para a porta, abrimos um pano, um pano vermelho com letras brancas: "Parai! Assisti ao comício do Bloco Operário”. Ele [Minervino de Oliveira] de um lado, e eu [Octavio Brandão] do outro. E aquela massa parava. Nós subíamos numa pedra, num banco, num caixão, em qualquer coisa. E começávamos: “pá, pá...”. Explicando. Fizemos cerca de sessenta comícios nas grandes empresas. 
Imaginem vocês! Comício nas três grandes fábricas da Gávea. Comício nas Laranjeiras, que era uma fábrica de tecidos muito importante, grande... Comícios lá no Moinho Inglês, na Saúde. Comícios lá em Deodoro. Comícios no Engenho de Dentro. Nas grandes empresas. Falando assim diretamente, virando a cabeça dos operários. Eram massas completamente... que não sabiam nada de nada. $\mathrm{E}$ distribuindo o programa do Bloco Operário e Camponês e o manifesto especial e tudo mais. Esses comícios e manifestos foram decisivos (Rego, 1993).

Os candidatos do BOC enfrentaram árduos obstáculos, quer na campanha e apuração dos votos, quer no reconhecimento pelo novo Conselho Municipal. Pudera, naquela época o voto não era obrigatório e o eleitorado numericamente reduzido; votavam apenas os homens, brasileiros, maiores de 21 anos, alfabetizados e alistados como eleitores. Os candidatos ou chefes políticos costumavam arregimentar seu próprio eleitorado por intermédio da ação dos chamados "cabos eleitorais", o que propiciava fraudes diversas, como não havia voto secreto, os eleitores ficavam à mercê de todo tipo de pressão (Pereira, 1976, p. 110). Diante do teste das urnas, Octavio Brandão recebeu 7.650 votos, sendo eleito em $10^{\circ}$ lugar no $1^{\circ}$ Distrito. Minervino de Oliveira recebeu 8.082 votos, ficando na $13^{\underline{a}}$ colocação no $2^{\circ}$ Distrito, onde se concentravam bairros habitados por muitos trabalhadores. Mas tal votação foi insuficiente para sufragá-lo em uma das doze vagas, até que uma fatalidade a morte acidental de um candidato eleito - abriu uma vaga e Minervino de Oliveira foi diplomado intendente do BOC no Conselho Municipal do Distrito Federal (O reconhecimento..., 1928). Pela primeira vez os comunistas conseguiram "fazer-se representar diretamente" em uma casa de leis no Brasil (Karepovs, 2006, p. 92). 
Ao iniciar os trabalhos do ano legislativo, Minervino de Oliveira não perdeu tempo e fez uso da tribuna já nas primeiras sessões de junho de 1929, leu o manifesto da Confederação Geral do Trabalho do Brasil e convocou o "proletariado" a se enfronhar na luta contra a "exploração capitalista". Seu primeiro pronunciamento "deixava transparecer o modo como o intendente comunista pretendia agir no Conselho", colocando o mandato a serviço da "solução proletária”, ele e Octavio Brandão buscaram inaugurar uma nova maneira de fazer política, na medida em que, cotidianamente, visitavam as fábricas e oficinas, os bairros operários e subúrbios pobres; organizavam novos comitês do BOC e auxiliavam as demandas operárias e sindicais. "Ao sair daqui todos os dias" - afirmou Minervino de Oliveira, em pronunciamento feito numa sessão de julho de 1929 - "dirijo-me ao seio do proletariado, que procuro às portas das fábricas, das oficinas, e nas organizações operárias”. Morador há mais de três anos de Campo Grande - bairro com grande número de indústrias e operários -, Minervino de Oliveira se posicionou na polêmica sobre a possível rescisão contratual da prefeitura com a Companhia Ferro Carril, uma empresa de transporte público de trem, que, ao que tudo indica, não estava prestando o serviço adequadamente, o que prejudicava o transporte dos operários daquela região. Em pronunciamento feito em outra sessão de julho, ele destacou que sua solidariedade não se restringia aos "proletários comunistas", mas aos "proletários em geral". ${ }^{9}$

Alguns intendentes reconheciam a importância da presença dos comunistas no Conselho Municipal, porém discordavam de sua linha de atuação. Um episódio contribuiu para agravar essa situação: por não se "acharem de acordo com a proposta dos diretores da Fábrica de Tecidos e Manufatora

9 Sobre o mandato de Minervino de Oliveira no Conselho Municipal do Distrito Federal, com uma análise de seus discursos e proposições, ver Silva (2013, pp. 171-179). 
Fluminense", em Niterói, os operários da empresa resolveram paralisar suas atividades no início de outubro de 1929, o sindicato da categoria enviou um representante para o local, "para servir de orientador do movimento, ao mesmo tempo de intermediário entre os paredistas e os patrões". As negociações não avançaram. Por meio de comício, "devido ao grande número de trabalhadores e da necessidade de todos eles participarem das resoluções sobre as medidas a serem tomadas", a categoria decidiu continuar o movimento; uma nova reunião entre os "paredistas e os patrões" foi agendada e um novo comício da categoria convocado.

Na manhã de 7 de outubro, Minervino de Oliveira e Octavio Brandão foram à cidade de Niterói participar do comício. Diante da multidão, discursaram, manifestando seu apoio às reivindicações do movimento. Foram presos e, ao tentar resistir, "metidos num 'tintureiro' aos empurrões e pontapés”, levados para a delegacia, ficaram num "xadrez 26 cheio de gente de toda espécie, com uma latrina que transbordava de fezes e fedia horrivelmente, provocando dor de cabeça” (A Greve..., 1929d; A policia..., 1929c; A Prisão...; 1929; A Sessão..., 1929; Ainda..., 1929; Brandão, 1978, pp. 363-364; Presos..., 1929).

Embora a Suprema Corte do país tenha arbitrado que os intendentes não poderiam ser presos (Conselho..., 1929), as autoridades policiais preferiram violar - mais de uma vez ${ }^{10}$ - a imunidade parlamentar de Minervino de Oliveira e Octavio Brandão, os quais só foram soltos cerca de 48 horas depois. De forma crescente, os dois passaram a ser cerceados e acusados de promover "propaganda subversiva e criminosa" e desvirtuar o mandato eletivo "outorgado pelo povo ordeiro e laborioso do Distrito Federal". Se isso dificultou a atuação deles no Conselho Municipal, não os impediu

\footnotetext{
10 Durante seu mandato como intendente, Minervino de Oliveira foi preso em outras ocasiões (As arbitrariedades..., 1929; O governo..., 1929; Os operários..., 1929).
} 
de usar aquele espaço para denunciar a violência policial nas greves, protestar contra a invasão da sede do BOC, a detenção de presos políticos ao lado de presos comuns, a apreensão do periódico A Classe Operaria e refregar pelas liberdades democráticas, pelo reconhecimento da União Soviética e pelo "internacionalismo proletário" (Brandão, 1978, p. 361).

Para os comunistas, a ação parlamentar estava subordinada à ação extraparlamentar do partido, e suas proposituras legislativas - em termos de discursos, requerimentos, indicações, projetos e emendas - deviam ser usadas como instrumento de agitação e propaganda. Minervino de Oliveira que o diga. O ano de 1929 foi bastante movimentado para ele; somente no campo sindical, acompanhou várias mobilizações operárias, prestou solidariedade ativa a diversas greves, sendo a mais notável a dos gráficos de São Paulo (A Gréve..., 1929a; A Gréve..., 1929b; A Gréve..., 1929c; A Greve..., 1929e; A Greve..., 1929f; “A Manhã”..., 1929; Protesto..., 1929), sem considerar que articulou a Liga Anti-Imperialista do Brasil (Está..., 1929) e presidiu o Congresso Operário Nacional, conclave realizado no Rio de Janeiro de 26 de abril a $1^{\circ}$ de maio e que contou com delegações da Bahia, Ceará, Mato Grosso, Pernambuco, Paraíba, Rio Grande do Norte, Rio Grande do Sul, São Paulo, Rio de Janeiro e Distrito Federal. Nesse Congresso deliberou-se pela fundação da Confederação Geral do Trabalho do Brasil (CGTB), sendo Minervino de Oliveira eleito seu secretário-geral. Ao término do evento, houve um grande comício comemorativo ao dia do trabalhador, o qual foi "realmente bastante prestigiado". ${ }^{11}$

11 Os agentes secretos da polícia se infiltraram no comício e produziram o seguinte relatório: "Finalmente o intendente Minervino de Oliveira, encerrando os trabalhos, fez um apelo a todas as Associações operárias ali representadas para que, regressando aos seus sindicatos, fizessem a maior propaganda possível da Confederação Geral do Trabalho, que dali em diante, seria o grande espantalho da burguesia, saudando, também, as associações dos Estados e desta Capital. O 
A vitória dos candidatos do BOC no Distrito Federal não só encheu de esperança a militância comunista, como ainda redobrou os ânimos para que o trabalho em prol do crescimento da "frente única" se ampliasse pelo país. A direção do PCB decidiu que o BOC iria se expandir por outros estados e mudaria sua estrutura organizativa, tendo em vista abrir comitês nos locais de trabalho (Karepovs, 2006, p. 127). De 3 a 5 de novembro de 1929 aconteceu o I Congresso do BOC, na cidade do Rio de Janeiro, que foi clandestino num recinto "perdido entre a estação de Campo Grande e Guaratiba" - porque a maioria dos intendentes recusou disponibilizar o prédio do Conselho Municipal para a realização do evento. Ainda teriam sido procurados os diretores de vários teatros, clubes e cinemas, mas estes, ligados aos "plutocratas, negaram-se a alugar um espaço aos trabalhadores" (Realiza-se..., 1929).

No Congresso se fizeram presentes mais de trinta delegados, representando 44 entidades de doze estados brasileiros. Afora ter alterado o nome da organização para Bloco Operario e Camponez do Brasil, o certame aprovou um novo programa que, em linhas gerais, preconizava a necessidade de o proletariado (da cidade e do campo) aliar-se com as camadas médias da população e ambos realizarem uma ação conjunta contra a burguesia. Sob a hegemonia dos trabalhadores industriais, essa aliança tinha a tarefa de impulsionar uma revolução agrária e anti-imperialista, etapa preliminar da revolução proletária (Del Roio, 1990).

Algumas das principais novidades do programa residiam nas reivindicações ligadas à cidadania e à incorporação dos setores específicos da sociedade, procurou-se contemplar as questões da juventude, das mulheres, dos

comício terminou com o cântico da 'A Internacional'” (Confederação..., [192-?]). Sobre o Congresso e comício de encerramento, ver ainda "Congresso operário nacional" (1929), "O proletariado do Brasil, pujante, coheso e disciplinado, viveu hontem um dos seus dias mais gloriosos” (1929) e Gomes (2005, p. 162). 
militares, dos trabalhadores rurais e até dos índios, contudo, silenciou-se em relação à chamada "questão negra". Um dos pontos altos do Congresso foi a discussão em torno do candidato da legenda ao cargo de presidente da República. Manteve-se a política de "candidaturas operárias", prova disso foi a escolha do marmorista Minervino de Oliveira. Era a primeira vez na história do Brasil que um trabalhador, negro e comunista disputaria esse cargo. Como vice de sua chapa, foi indicado o ferroviário Gastão Valentim Antunes; já no que diz respeito aos candidatos a senador e deputado federal pelo Distrito Federal, aprovou-se o nome do estivador Phenelon José Ribeiro para senador e os nomes do gráfico Mário Grazzini e do advogado Paulo Lacerda para deputados federais.

A sessão solene de encerramento do I Congresso do BOC transcorreria no dia 6 de novembro, sob o pretexto de que uma "reunião de comunistas não podia deixar de constituir uma ameaça à ordem pública”, a polícia agiu de forma implacável: no início da noite concentrou-se nas imediações da residência de Octavio Brandão - local indicado para o evento - e prendeu dezenas de indivíduos que para lá se dirigiam, até mesmo alguns jornalistas. Encaminhados para a $4^{\mathrm{a}}$ Delegacia Auxiliar, ${ }^{12}$ todos foram submetidos à identificação digital e postos em liberdade horas depois. Para o Diário Carioca, tratava-se de "mais uma revoltante manifestação reacionária e brutal” do governo Washington Luís, que "procura impedir, o operariado,

12 A 4 $4^{\mathrm{a}}$. Delegacia Auxiliar surgiu em 1922, em substituição à Inspetoria de Investigação e Segurança Pública. Mantinha uma das suas seções, a Seção de Ordem Política e Social, como órgão para vigiar e garantir a ordem social da República. Uma de suas prerrogativas era a de intervenção contra qualquer manifestação ou modalidade de "anarquismo violento", o que podia ser interpretado como qualquer movimento contestatório de caráter político. Naquele momento, as seções da "polícia política" não só sofisticaram seus métodos de vigilância e investigação, como também ampliaram a quantidade e truculência de suas ações. (Mattos et al., 2004). Sobre a repressão aos movimentos sociais na Primeira República, ver ainda Loner (2015). 
o exercício dos mais rudimentares direitos que o nosso regime assegura a todos os cidadãos”. O Bloco Operario e Camponez seria uma "organização que procura exercer, dentro do sistema legal vigente, a atividade política, participar, pacificamente, como todas as expressões da opinião, de um pleito político" (A acção... 1929; A policia... 1929b; Foi..., 1929).

No dia seguinte houve um comício na Praça Marechal Floriano - conhecida atualmente como Cinelândia -, centro do Rio de Janeiro, com o objetivo de comemorar o décimo-segundo aniversário da Revolução Russa e apresentar publicamente os candidatos do BOC à presidência da República. Às quatro horas da tarde os "secretas" já se encontravam de prontidão nas adjacências. Por volta das quatro horas e quarenta e cinco minutos, tomou a palavra Minervino de Oliveira, que protestou contra a arbitrariedade policial no dia anterior e rendeu tributos à Revolução Russa. A cada pausa de seu discurso o "intendente comunista" era saudado por "vibrantes salvas de palmas e gritos partidários". Ao final, ele anunciou os nomes dos candidatos do BOC escolhidos durante o I Congresso, quando ia falar Mário Grazzini - gráfico e candidato a deputado federal -, os agentes policiais agarraram-no pelo pescoço, impediram-no de discursar e o levaram detido.

Seus companheiros se opuseram, mas "os secretas responderam, sacando seus revólveres e alvejando os presentes". A polícia então resolveu avançar contra a multidão, desferir cacetadas, atirar a esmo e dissolver o comício violentamente. Instaurou-se o pânico. Os populares se dispersaram entre correrias e atropelos, alguns dos quais invadiram estabelecimentos comerciais, que cerraram as portas, e improvisaram refúgios nos carros das cercanias da praça. Como saldo final, cerca de cem pessoas presas (entre operários, transeuntes e até jornalistas) e três feridas, das quais duas à bala. As presas foram conduzidas à delegacia no 
edifício da central de polícia, onde se viram identificadas e postas em liberdade (As violencias..., 1929a; Foi..., 1929; Minervino..., 1929; O comicio..., 1929b; O dia..., 1929; Os comunistas..., 1929).

Tanta truculência contra os "comunistas" causou indignação por parte de um setor da imprensa: "o que se praticou, anteontem, e ontem, foi um inútil e estúpido atentado à liberdade de reunião", qualificou a reportagem d'A Manhã (Foi..., 1929). ${ }^{13}$ "Ação violenta e anticonstitucional da polícia civil", eis como preferiu definir O Jornal (O comício..., 1929a). O intendente Maurício de Lacerda usou a tribuna do Conselho Municipal para criticar os atos "autoritários" e "ditatoriais" desferidos contra o BOC que, embora fosse um partido político "extremista" - ponderou -, tinha o "direito de ter o pensamento e o programa que bem entender" (As violencias..., 1929b).

\section{"Votar no Bloco Operario e Camponez é votar pela Revolução!"}

Com os nomes dos candidatos anunciados às eleições majoritárias e proporcionais no Distrito Federal e nos estados do Ceará, Espírito Santo, Paraíba, Pernambuco, Rio Grande do Sul, Rio de Janeiro e São Paulo, o BOC lançou-se à campanha de Minervino de Oliveira, cujo slogan era "Votar no Bloco Operario e Camponez é votar pela Revolução!”. Seu programa de governo preconizava propostas avançadas para a época, como a nacionalização de algumas empresas estrangeiras, o fim das leis de exceção, a anistia aos presos políticos, o voto secreto e a criação de uma legislação trabalhista (com jornada de trabalho de no máximo oito horas diárias e 44 horas semanais, salário mínimo, contratos coletivos de trabalho, seguro social etc.). No que tange

13 Para a crítica da ação policial no comício do BOC, ver também o artigo: "O maior propagandista do communismo" (Nazareth, 1929). 
às questões dos grupos específicos, o programa do BOC defendia alguns direitos das mulheres, dos analfabetos, dos militares, dos menores, dos índios; porém, mais uma vez, silenciava-se a respeito da "questão negra".

Foi definida uma estratégia de campanha que previa a organização de comitês em algumas capitais e cidades do interior; a realização de visitas (às portas de fábricas, aos bairros operários e aos sindicatos), comícios e festivais; a participação em atividades, assembleias e debates políticos; a distribuição de material de propaganda (folhas volantes, cartazes, jornais e manifestos) e a confecção de cédulas eleitorais. Previa-se ainda a convocação dos ativistas para prestarem serviços no dia das eleições, garantido o transporte dos eleitores e o deslocamento de fiscais pelas seções.

Em sua edição de 11 de dezembro, a Gazeta de Notícias informou que a "campanha de repressão à propaganda comunista", que a polícia vinha exercendo "tenazmente", experimentou no dia anterior "mais uma diligência de efeitos frutuosos" (Reprimindo..., 1929). Foram apreendidos alguns milhares de prospectos, que eram atribuídos a Minervino de Oliveira, e preso o carregador José Serafim de Souza que, na ocasião, conduzia os prospectos do Instituto de Artes Gráficas, da rua dos Inválidos, 180-A, para a rua Paulo Frontin, 103, onde deveriam ser cortados e preparados para a distribuição. O candidato do BOC e seus correligionários eram acusados de representantes da "propaganda subversiva de Moscou" e de patrocinar o "ataque sistemático às instituições atuais - à pátria, à família e às religiões, principalmente à católica" (Em polvorosa..., 1929). O clima de intolerância aos comunistas recrudesceu, razão pela qual a campanha de Minervino de Oliveira acabou se caracterizando mais como uma sucessão de desrespeito às liberdades públicas - perseguições, dissoluções de comícios e prisões arbitrárias - que um movimento de agitação política, 
disputa de ideias e disseminação de posicionamentos classistas (Karepovs, 2006, p. 158).

No início de 1930, viajou para a cidade de Ribeirão Preto, no interior de São Paulo, para presidir o "Congresso dos colonos e trabalhadores agrícolas" e participar das atividades de campanha. A solenidade de encerramento do conclave ocorria no dia 12 de janeiro, um domingo, e reunia mais de duzentas pessoas, na maioria "colonos", embora as principais lideranças comunistas da região também se fizessem presentes. O candidato do BOC palestraria por volta das 13h00, quando apresentaria seu programa de governo, mas, momentos antes, cerca de vinte policiais e alguns agentes secretos da Delegacia de Ordem Política e Social invadiram a sede da entidade sindical de revólveres em punho, desbarataram o Congresso e o prenderam, junto com os demais componentes da mesa diretora (O Sr. Minervino..., 1930). "Foi uma verdadeira balbúrdia", resumiu a reportagem do Diário Nacional (Municipios, 1930). Minervino de Oliveira foi enviado ao "Gabinete de Investigações" da delegacia regional, onde permaneceu encarcerado durante vários dias (Protestae..., 1930). ${ }^{14}$ Para o jornal A Batalha, a prisão dele consistiu um total "absurdo", que só a "mentalidade medieval" daqueles dias explicaria e contra a qual "nós levantamos o nosso protesto" (A prisão..., 1930). ${ }^{15}$

As autoridades policiais ignoravam a imunidade parlamentar do intendente do Distrito Federal então pleiteante ao cargo de presidente da República. Mais ainda: procuravam tolher as manifestações de sua campanha eleitoral, promovidas em espaços públicos, nos limites constitucionais do direito de reunião. O lema era intensificar a vigilância sob pena de ter, mais tarde, que usar medidas extremas para combater os que postulavam "doutrinas políticas exóticas”.

\footnotetext{
14 Sobre a prisão de Minervino de Oliveira no Congresso dos colonos e trabalhadores agrícolas, ver ainda Rosa (1997, pp. 82-83).

15 Ver também "A angustiosa situação da lavoura paulista" (1930).
} 
Já para Minervino de Oliveira, o lema era fazer da campanha uma arena de mobilização e difusão dos anseios e projetos dos trabalhadores no campo da luta de classes, ou, antes, utilizá-la como meio oportuno para poder o proletariado se organizar e estar, então, preparado para outros embates futuros no sentido da revolução. Em mais de uma vez ele - que era acossado por agentes dos órgãos de repressão (Confederação..., [192-?] ) ${ }^{16}$ e por isso mesmo abandonou seu lar e passou a viver na clandestinidade desde o final de 1929 - declarou à imprensa: "não reagiremos às arbitrariedades da polícia, mas havemos de chegar ao grande dia e então, os que gostam de violências, não poderão conter as nossas represálias. Estou convencido que só venceremos pela revolução" (Foi..., 1929). ${ }^{17}$

Segunda quinzena de janeiro. A cidade de Petrópolis, na região serrana do Rio de Janeiro, foi alvo da ação do BOC, sob a influência da organização, os operários das 34 fábricas de tecido da cidade paralisaram suas atividades, reclamando por melhores condições de trabalho e reajuste salarial. Também trabalhadores de outros setores, como os das casas comerciais e das oficinas da Leopoldina Railway, cruzaram os braços e se ausentaram de seus postos de trabalho. As autoridades locais ficaram em polvorosa e pediram providências ao delegado Abel Assumpção, da $1^{\underline{a}}$ Delegacia Auxiliar do estado do Rio de Janeiro. Imediatamente, foram

16 Em nota pública, a direção do BOC alardeou que Minervino de Oliveira recebia ameaças constantes, sendo "dia e noite" acuado pelos "motins policiais" (Protestai..., 1930).

17 Consta que Minervino chegou a ser até alvo de emboscadas por parte do aparato de repressão política. Octavio Brandão relata ao menos um episódio dessa natureza, no começo de 1930, o PCB havia marcado um comício em Madureira, os agentes de polícia tomaram posição para matar os oradores - Minervino de Oliveira, Paulo de Lacerda e Octavio Brandão. Foram "mesmo designados os assassinos. Cada um deveria responder pelo cumprimento da ordem recebida e atirar para matar. Para nós, a solução foi passar ao largo da emboscada. Posteriormente, um agente da polícia de Washington Luís, preso pelo governo de Getúlio Vargas, na Casa de Detenção, contou-me detalhes a respeito dessas emboscadas" (Brandão, 1978, pp. 377-378). 
enviados agentes policiais para garantir o funcionamento das fábricas, oficinas e casas comerciais. De acordo com o diário A Noite, o "intendente" Minervino de Oliveira era o "insuflador" do movimento de Petrópolis. O "edil comunista" estava na cidade serrana agitando os operários, liderando greves e organizando um comício de divulgação de sua candidatura à presidente do Brasil (A acção..., 1930a). A Gazeta de Notícias, que igualmente atribuía ao "edil comunista" a responsabilidade pelo que vinha ocorrendo em Petrópolis, fazia um alerta: "Esse indivíduo, que está desafiando demais o poder constituído e a ordem do país, precisa ser vigiado assiduamente, seguidos os seus passos, para que não mais venham a se reproduzir fatos como esses que causam transtornos facilmente avaliáveis, pondo em sobressalto o povo ordeiro do país" (Os communistas..., 1930).

Boa parte da grande imprensa não nutria simpatia pelo candidato do BOC. No dia 22 de janeiro, A Noite publicou um artigo cujo título e subtítulo remetem a isso: "Um desafio à lei, à sociedade e aos poderes públicos. A ação perturbadora e intencional dos comunistas, no Rio, em São Paulo, em Niterói e em Petrópolis”. Pelo julgamento do periódico, era Minervino de Oliveira quem, "em todos esses casos", agia "como insuflador dos vários movimentos", fazendo a propaganda da "invasão da onda vermelha da Rússia". Sua "criminosa atividade" era voltada para os "meios laboriosos, em que incentivava o espírito de rebelião e determinava a paralisia de estabelecimentos industriais, pelo vicioso prazer de arrastar-nos a horas de amarguras, nos deveres da repressão" (Um desafio..., 1930).

11 de fevereiro. Nova privação de liberdade do candidato do BOC. A Batalha noticiou que, naquela data, após a realização de um comício eleitoral de campanha em Bangu - bairro da zona Norte do Rio de Janeiro -, Minervino de Oliveira foi preso por investigadores de polícia ao deixar as "cercanias da Fábrica de Tecidos Bangu", por volta das 17h00. Além dele, foram detidos o advogado Paulo de Lacerda e o 
gráfico Mário Grazzini, candidatos do BOC à deputação federal. Conduzidos ao 25ํㅗㅇ Distrito Policial, todos dali se viram mais tarde transferidos em "tintureiro" para a 4" Delegacia Auxiliar. Segundo a reportagem, eram 23 horas quando Minervino de Oliveira deixou aquela repartição policial, tendo lá ficado ainda seus "companheiros de propaganda" político-eleitoral (Foi..., 1930; Foram..., 1930). Madrugada de 22 de fevereiro, uma turma de agentes da $4^{\underline{a}}$ Delegacia Auxiliar, chefiada pelo comissário Martins Vidal, prendeu numa velha casa da estação Bento Ribeiro onze operários filiados ao BOC, que ali tratavam da propaganda da candidatura do intendente Minervino de Oliveira à presidência da República. Em diligência na casa, os "secretas" encontraram prospectos de propaganda e manifestos solicitando votos para o intendente (A prisão..., 1930b; Preparando..., 1930).

Última semana de fevereiro. Mais uma contenção do candidato comunista. Ao viajar para a capital paulista, seu plano era se deslocar até Santos para participar de um comício, em outro compromisso de campanha, sua chegada à cidade litorânea estava marcada para ocorrer no trem das $18 \mathrm{~h} 00$. Compareceram à estação ferroviária muitos de seus correligionários e "vários admiradores das ideias pregadas pelo Bloco Operario e Camponez". Segundo o Diário Nacional, a estação, não sendo privilégio dos que foram esperar o intendente carioca, estava na ocasião cheia dos que embarcavam e desembarcavam e dos que circulavam por lá a serviço ou a passeio. Nada disso, porém, conteve a polícia que, rispidamente, investiu "contra todos sem distinção, foi efetuando grande número de prisões [mais de noventa], não obstante os protestos e as credenciais dos que não tinham cousa alguma que ver com o intendente carioca". Apesar da ampla expectativa, Minervino de Oliveira não chegou ao litoral paulista, pois a "polícia de São Paulo, naturalmente querendo impedir que a sua colega de Santos tivesse tantos 'trabalhos', agarrou o intendente carioca na capital. Mas, infelizmente, 
não teve tempo de avisar à polícia a fim de evitar as desagradáveis ocorrências verificadas" (Porque..., 1929). ${ }^{18}$

As autoridades ligadas aos governos estaduais dificultaram ao máximo a campanha do BOC. O aparato de forças policiais confiscou A Classe Operaria, jornal dedicado à propaganda eleitoral da agremiação, bem como impediu a realização de meetings em alguns bairros do Distrito Federal. Diversos indivíduos que distribuíam panfletos e material de propaganda de Minervino de Oliveira foram presos. Aliás, a própria detenção do intendente carioca e de seus partidários tornou-se um expediente comum. Na madrugada de 28 de fevereiro, os "secretas" do Rio de Janeiro invadiram altas horas da noite a residência do operário José Francisco da Silva, candidato pelo BOC ao Senado, removendo-o para a polícia central, onde continuou no "xadrez" e incomunicável até o dia das eleições. Paulo de Lacerda, candidato da agremiação à deputação federal, foi preso quando tentou realizar um comício em frente a uma fábrica de tecidos da Gávea. A voz de prisão foi-lhe dada por um delegado cujo irmão também se candidatara ao Congresso. Fernando de Lacerda - médico e irmão de Paulo - queixou-se de ameaças feitas à sua vida, caso fizesse propaganda para o BOC na Gávea. Domingos Braz - candidato pela legenda a deputado no $1^{\circ}$ Distrito do estado do Rio de Janeiro - foi preso em Petrópolis e remetido para a 4ª Delegacia Auxiliar. Em São Paulo, Aristides Lobo - também candidato a deputado - viu-se detido e expulso, posteriormente, da capital bandeirante. Centenas de operários foram encarcerados arbitrariamente e sofreram maus tratos nas cidades paulistas de Santos, Ribeirão Preto, Sertãozinho e Catanduva, assim como na capital do estado. Proibições de atividades de propaganda, perseguições, enclausuramentos forçados e agressões aos

18 Ver também "A annunciada viagem do Sr. Minervino de Oliveira a S. Paulo" (1930), "Parece que o sr. Minervino de Oliveira, não tendo chegado a Santos, foi detido em S. Paulo" (1930) e "90 prisões em Santos" (1930). 
comícios do BOC foram igualmente registrados em Minas Gerais (especialmente nas cidades de Belo Horizonte e Juiz de Fora) e no Rio Grande do Sul. Neste último estado, Plínio Melo foi detido, submetido a supostas torturas e deportado para o Uruguai antes do dia das eleições (Protestai..., 1930).

Os atos de repressão contra os comunistas dificultaram o trabalho de agenciamento e propaganda do BOC, sem falar que prejudicaram a estrutura montada de cooptação de novos aderentes à campanha. $\mathrm{O}$ alistamento eleitoral viu-se inteiramente comprometido diante das constantes invasões realizadas pelos "secretas" nas sedes dos comitês do BOC, já que geralmente redundavam no confisco da documentação política ou na destruição do material de propaganda, quando não tais invasões afugentavam os eleitores simpatizantes da agremiação, tanto pela incerteza de poder encontrar os comitês em funcionamento como pelo receio de sofrer alguma represália policial (Karepovs, 2006, p. 158).

Sábado, primeiro de março de 1930. Finalmente chegou o dia das eleições. Foi um pleito aguardado com expectativas e disputado num clima de tensão e rivalidade. Durante todo o dia o aparato policial ficou de plantão. Isto, contudo, não impediu que as oligarquias - quer as tradicionais quer as dissidentes - acionassem os velhos e viciados métodos políticos da manipulação, corrupção e violência (O grande..., 1930). Assim procedendo, coibiram a possibilidade de o BOC surpreender. Se não bastassem suas cédulas eleitorais só terem sido distribuídas às vésperas das eleições, seus cartazes deixarem de ser colados em vários locais e seu material de propaganda ter circulado abaixo das expectativas, a agremiação não conseguiu designar fiscais para acompanhar o trabalho das seções de votação e teve sua "boca de urna" desarticulada. Tais fatos retratam apenas o que ocorreu no Distrito Federal, onde o BOC era mais bem estruturado, não sendo difícil, portanto, supor o que transcorreu em outras localidades do vasto território nacional (Dulles, 1977, p. 344). 
O candidato situacionista Júlio Prestes saiu-se vencedor, à frente de Getúlio Vargas e, como de costume, a fraude campeou de todos os lados (A fraude..., 1930). Estima-se que a população brasileira em 1930 era de 40.158 .925 pessoas, das quais 2.941.778, ou seja, 7,32\%, formavam o eleitorado. Compareceram às urnas 1.900 .256 eleitores, o que correspondia a $64,59 \%$ do eleitorado total e $4,73 \%$ da população brasileira. O resultado final - sancionado pela Mesa do Congresso Nacional em 20 de maio de 1930 - apontava que Júlio Prestes recebera 1.091.709 votos válidos $(57,44 \%)$, Getúlio Vargas obtivera 742.794 (39,09\%) e 65.753 (3,47\%) haviam sido anulados. Com efeito, as fraudes tornavam esses números pouco confiáveis. No que tange à votação dos candidatos a presidente e a vice do BOC, não existem números precisos. Se com base nos pareceres das comissões especiais de apuração do Congresso Nacional, Minervino de Oliveira recebeu 720 votos, os documentos do PCB da época registraram três ou quatro mil (Karepovs, 2006, pp. 158-161).

Júlio Prestes ganhou as eleições, porém não chegou a ser empossado. Getúlio Vargas e os "caciques" da Aliança Liberal não se conformaram com a derrota e passaram a conspirar um golpe de Estado. Contando com o apoio de grupos civis e militares, sobretudo os "tenentes", lideraram um movimento armado no início de outubro que resultou na deposição do Presidente Washington Luís por uma junta militar. A Junta logo cedeu o governo a Vargas, que assumiu o poder em 3 de novembro. Este fato - conhecido como a Revolução de 1930 - marcou o fim da Primeira República e o início de novos tempos, naquela altura ainda nebulosos. Revelando sua faceta autoritária, o novo governo determinou o fechamento do Congresso, dos Legislativos Estaduais e Municipais e dos partidos políticos. Os "tenentes" e alguns poucos dirigentes da Aliança Liberal passaram a ocupar os postos políticos de destaque. A repressão ao comunismo continuou com tanta ou mais intensidade do que antes. 
Um editorial do Jornal do Brasil, intitulado "Atividade comunista", saudava a repressão e a "severa vigilância em torno de elementos que se mostram partidários do comunismo" (Ecos..., 1930). O novo chefe de polícia, o General Bertoldo Klinger, "em declarações pelos jornais e grandes cartazes grudados nas paredes, ameaçava fuzilar todos os comunistas e bradava como um possesso: 'As feras serão tratadas como feras"” (Brandão, 1978, p. 396).

Minervino de Oliveira teve o seu mandato de intendente praticamente caçado, o que reforçou nele e nos seus companheiros do PCB o entendimento de que a Revolução de 1930 foi uma "quartelada pequeno-burguesa contra o povo" e para "evitar a revolução das massas" (Segatto, 1989, pp. 40-41; Silva, 2002). Por ter falado num meeting de contestação ao governo golpista na praça Mauá, foi preso e mandado para a Casa de Detenção, depois de ter passado vinte dias na Casa de Correção, durante o governo de Washington 40 Luís (Dois..., 1930; Dulles, 1977, p. 359). Mesmo quando os adversários do antigo regime foram anistiados e postos em liberdade, Minervino de Oliveira permaneceu na masmorra. Era um preso político visto como perigoso. Seu filho primogênito, o menor João Chrisostomo de Oliveira, fez apelos ao chefe de polícia do Distrito Federal para tentar libertá-lo, sob a alegação de que a família - que vivia numa pequena casa na Estrada da pedra, 44, Guaratiba - padecia em estado de "penúria". Sua mãe se encontraria "gravemente enferma", em consequência do parto recente, além de "abalada por tantos sofrimentos e com seis filhos menores e sem recursos" (A prisão..., 1930a). ${ }^{19}$ Em vão. Somente após quase 100 dias seu pai foi solto, em fevereiro de 1931 (Minervino..., [192-?]; Uma reunião..., 1931).

19 Ver também "Os 'saldos' do governo Washington Luis" (1930) e "Apello ao Dr. Baptista Luzardo” (1930). 
A partir dali pouco se sabe da trajetória de Minervino de Oliveira. Talvez tenha sido expulso do PCB, como aponta Davino Franciso Santos em livro de memórias (Santos, 1948, p. 232). Ou talvez tenha se cansado de tantos reveses e se afastou dessa agremiação partidária, para investir em outros projetos na vida, embora não tenha abandonado a militância na categoria profissional que o revelou para o mundo da política: os marmoristas. ${ }^{20}$ Seja como for, o pioneirismo de Minervino de Oliveira já havia se inscrito nos anais da história, afinal, ao lado de Octavio Brandão, foi o primeiro parlamentar comunista no Brasil, assim como o primeiro negro e operário a disputar o cargo mais importante da nação, a presidência da República.

Se sua candidatura, por um lado, expressou uma alternativa classista, vinculada aos interesses dos trabalhadores, por outro, negligenciou as questões de raça. Por que será que isso aconteceu? É difícil dar uma resposta segura e definitiva, com efeito vale a pena tentar entender essa negligência. Minervino de Oliveira foi talhado pelo Partido Comunista, organização política "revolucionária" que, segundo Pedro Chadarevian, não se debruçou sobre a "questão negra" por cerca de uma década - da sua fundação em 1922 até o início da década de 1930. A primeira manifestação do PCB sobre o assunto data de 1923. O partido foi questionado pela Internacional Comunista (IC, ou Comintern), sediada em Moscou, a respeito da formação racial brasileira, ao que Octavio Brandão respondeu taxativamente que havia negros no Brasil, mas não uma “questão negra”. No relatório

\footnotetext{
20 Em livro de memórias, Carlos Lacerda define Minervino de Oliveira como um "marmorista de escol" (Lacerda, 2001, p. 141). Na imprensa regular, há menções à atuação do ex-intendente como orador do Comitê Democrático Progressista dos Marmoristas, em 1945, e como orador do Sindicato dos Marmoristas do Rio de Janeiro, em 1955. Ver "Patrões e operários num ambiente de cordialidade" (1945) e Souza (1955).
} 
enviado à IC por ocasião do VI Congresso (1928), o PCB denunciava as difíceis condições de vida dos índios, porém se omitia em relação aos negros. Os delegados brasileiros que participaram do Congresso teriam negado "categoricamente o problema das raças" em seu país (Chadarevian, 2012, pp. 259-260).

Em junho de 1929, realizou-se a I Conferência Comunista Latino-Americana em Buenos Aires. Um mês antes, Jules Humbert Droz - dirigente comunista enviado pela IC para acompanhar o evento - viajou pela América do Sul para conhecer in loco a conjuntura dos países da região a fim de melhor qualificar-se para a Conferência. "Segundo as informações de nossos camaradas", registrou o líder comunista suíço em sua passagem por Pernambuco, "não existem preconceitos de raça no Brasil” (Droz, 1979, p. 310). Durante a Conferência, os delegados brasileiros defenderam a tese de que a situação dos negros compatriotas não demandava, por parte dos comunistas, "campanhas reivindicativas" específicas. Apontaram para o elevado grau de mestiçagem e a tendência de branqueamento da população brasileira, além de mencionarem o significativo número de não brancos ocupando cargos importantes nos estratos da burguesia. Eis as razões pelas quais concluíram que não havia preconceito racial no Brasil, e que o problema do negro era de classe e não de raça (Chadarevian, 2012, p. 260).

A reviravolta, que viria provocar a mudança na orientação do PCB em relação à "questão negra", derivou de uma série de críticas efetuadas pelo comitê executivo da IC. Desde 1928 Moscou adotava a política do direito à autodeterminação dos negros e indígenas. Tal política prometia garantir a soberania econômica, política e cultural desses grupos, deixando-os constituir seus próprios Estados, se assim desejassem. Em outros termos, "negros e indígenas foram declarados 'nacionalidades' raciais oprimidas, que mereciam o direito de se autogovernar em Estados 
independentes" (Graham, 2014, pp. 355-356). Foi se valendo dessa diretriz que, em reunião extraordinária realizada em Moscou no início de 1930, os dirigentes da IC aprovaram uma resolução sobre o Brasil, com críticas contundentes ao PCB. Dentre as tarefas imediatas exigidas à agremiação da América do Sul, destacava-se a necessidade de empreender um trabalho "sério" e "sistemático" contra a opressão racial. Um ano depois, Moscou enviou à direção do PCB um questionário solicitando informações sobre a situação dos negros no Brasil. As questões deveriam servir de base para a formulação de uma nova agenda voltada a esse segmento populacional (Chadarevian, 2012, p. 261-262).$^{21}$ A partir dali o PCB reavaliou tanto o trabalho político quanto o tratamento teórico conferido à questão racial. Não havia mais lugar para a negação da "questão negra".

É importante frisar que quando Minervino de Oliveira candidatou-se à presidência da República em 1929, o PCB desinteressava-se pelos problemas específicos do afro-brasileiro ou mesmo subestimava a existência do racismo na comunidade nacional. ${ }^{22}$ Por isso não é de estranhar que ele - um operário militante fiel e devotado ao programa "revolucionário" do partido - tenha negligenciado as questões de raça durante a campanha. Sua condição de negro era vista como secundária em relação à sua condição de classe. Isso não impediu que, depois de ter caído no ostra-

21 Para uma pesquisa recente sobre a pressão realizada pelo Comintern ao PCB no que diz respeito à "questão negra" e a inflexão deste partido na definição dos contornos de uma nova política para o assunto, ver Lima (2015).

22 Entre as correntes político-ideológicas com inserção nos movimentos sociais, os comunistas não foram os únicos a subalternizarem a luta antirracista. Segundo Tiago Bernardon de Oliveira, os anarquistas também não concebiam a "questão negra" como específica e seus militantes viam-se como brancos. Isto significa que, apesar do discurso em defesa de "todas as raças", tinham os trabalhadores brancos como "público prioritário a atingir". Era "nos trabalhadores brancos, sobretudo os estrangeiros, que aqueles militantes depositavam a fé de poder arregimentar com mais facilidade forças para a cotidiana batalha revolucionária, para libertar todas as raças do jugo da escravidão capitalista" (Oliveira, 2009, p. 243). 
cismo, Minervino de Oliveira tenha sido revalorizado por uma memória negra comunista. Em 2014, um grupo de negros ligados ao Partido Comunista Brasileiro (PCB) fundou no Rio de Janeiro o Coletivo Minervino de Oliveira. Este nome não foi escolhido à toa. Segundo consta na página do Coletivo na internet, tratou-se de uma homenagem àquele que "se destacou na história do movimento negro brasileiro, sendo o primeiro negro candidato à presidência da República do Brasil, pelo Partido Comunista Brasileiro (PCB) em 1928, denunciando o mito da democracia racial e apontando os limites da sociedade capitalista e a necessidade de superá-la" (Coletivo..., [20-?]).Eis uma narrativa típica da politização da memória, facilitada graças às idealizações e reinterpretações dos fatos da história. De símbolo operário e comunista, Minervino de Oliveira passa agora a ser apropriado e celebrado como ícone negro, uma espécie de herói da luta antirracista. Mas é bom lembrar: heróis são invenções poderosas, nortes de referências e identificação coletiva, encarnações de ideias e aspirações que permitem fazer a cabeça e tocar o coração das pessoas em vista da legitimação de projetos políticos (Carvalho, 1990, p. 55).

\section{Petrônio Domingues}

é doutor em História pela Universidade de São Paulo e professor da Universidade Federal de Sergipe (UFS).

\section{Bibliografia}

90 prisões em Santos. A Batalha, Rio de Janeiro, 28 fev. 1930, p. 1.

A ACÇÃO da policia contra o communismo. A Noite, Rio de Janeiro, 7 nov. 1929, p. 2.

A ACÇÃO dos comunistas! A Noite. Rio de Janeiro, 21 jan. 1930a, p. 3.

A ACÇÃO, nefastamente ridícula, de pretensos discípulos de Lenine. $O$

Paiz, Rio de Janeiro, 22 jan. 1930b, p. 2.

A ANGUSTIOSA situação da lavoura paulista. O Jornal, Rio de Janeiro, 17 jan. 1930, p. 16. 
A ANNUNCIADA viagem do Sr. Minervino de Oliveira a S. Paulo. O Jornal, Rio de Janeiro, 25 fev. 1930, p. 2.

A FRAUDE na 3ํㅗㄹ Seção da Gamboa. Diário da Noite, Rio de Janeiro, $1^{\circ}$ mar. 1930, p. 9.

A GRÉVE dos graphicos de São Paulo. Critica, Rio de Janeiro, 5 abr. 1929a, p. 5 .

A GRÉVE dos graphicos paulistas. Critica, Rio de Janeiro, 18 abr. 1929b, p. 5. A GRÉVE dos graphicos paulistas. Critica, Rio de Janeiro, 15 maio 1929c, p. 6. A GRÉVE dos marmoristas. A Razão, Rio de Janeiro, 15 jun. 1919, p. 5.

A GREVE dos operarios da manufatura Fluminense. Diário Carioca, Rio de Janeiro, 8 out. 1929 d, p. 4.

A GREVE dos operarios graphicos de S. Paulo. O Jornal, Rio de Janeiro, 28 mar. 1929 e, p. 3.

A GREVE dos padeiros. OJornal, Rio de Janeiro, 12 abr. 1929f, p. 3.

“A MANHÃ" proletaria. A Manhã, Rio de Janeiro, 28 mar. 1929, p. 4.

A POLICIA contra os communistas. O Jornal, Rio de Janeiro, $10 \mathrm{dez}$. 1929a, p. 10.

A POLICIA impediu que se realizasse a sessão de encerramento do Congresso do Bloco Operario. Diário Carioca, Rio de Janeiro, 7 nov. 1929 b, p. 1.

A POLICIA prohibe um meeting de operarios. OJornal, Rio de Janeiro, 16 out. 1929 c, p. 5.

A PRISÃO de Minervino de Oliveira. Uma carta ao chefe de policia. $A$ Batalha, Rio de Janeiro, 7 dez. 1930a, p. 6.

A PRISÃO de onze communistas na estação de Bento Ribeiro. O Jornal, Rio de Janeiro, 23 fev. 1930b, p. 14.

A PRISÃO, em Nictheroy, dos intendentes cariocas Minervino de Oliveira e Octavio Brandão e da esposa deste. A Manhã, Rio de Janeiro, 8 out. 1929, p. 4.

A PRISÃO, em São Paulo, do intendente carioca Minervino de Oliveira. $A$ Batalha, Rio de Janeiro, 16 jan. 1930, p. 2.

A SESSÃO de hontem no conselho municipal. Critica, Rio de Janeiro, 10 out. 1929, p. 2.

A SIGNIFICAÇÃO das eleições para o proletariado. A Classe Operaria, Rio de Janeiro, 15 fev. 1930, p. 1.

AS ARBITRARIEDADES da policia do Snr. Manoel Duarte. A Manhã, Rio de Janeiro, 21 out. 1929, p. 4.

AS ELEIÇÕES municipaes de Outubro. A Esquerda, Rio de Janeiro, 22 set. 1928 , p. 2.

AS VIOLENCIAS da policia carioca. Diário Nacional, São Paulo, 8 nov. 1929a. 
AS VIOLENCIAS da policia contra os operarios. A Manhã, Rio de Janeiro, 9 nov. 1929 b, p. 4.

AINDA a prisão dos intendentes cariocas num comicio em Nictheroy. $O$ Jornal, Rio de Janeiro, 9 out. 1929, p. 3.

APELLO ao Dr. Baptista Luzardo. Diário Carioca, Rio de Janeiro, 9 dez. 1930, p. 6.

BATALHA, C. H. M. 2000. O movimento operário na Primeira República. Rio de Janeiro: Jorge Zahar.

2008. Formação da classe operária e projetos de identidade coletiva. In: FERREIRA, J.; DELGADO, L. A. N. (orgs.). O tempo do liberalismo excludente: da proclamação da República à Revolução de 1930. Rio de Janeiro: Civilização Brasileira, 2008, pp. 161-189. (Coleção o Brasil Republicano, v. 1).

. 2015. A Confederação Operária Brasileira e sua militância. In: MARQUES, A. J.; STAMPA, I. T. (orgs.). Arquivos e o direito à memória e à verdade no mundo dos trabalhadores. Rio de Janeiro: Arquivo Nacional; São Paulo: CUT, 2015, pp. 71-89.

BERNARDES, inimigo dos trabalhadores. A Crítica, Rio de Janeiro, 27 dez. 1928, p. 5.

BORGES, V. P. 1992. Tenentismo e revolução brasileira. São Paulo: Brasiliense. BRANDÃO, O. 1978. Combates e batalhas: memórias. São Paulo: Alfa-Omega. CARONE, E. (org.). 1979. Movimento operário no Brasil (1877-1944). São Paulo: Difel. 1982. O P.C.B. (1922-1943). v. 1. São Paulo: Difel.

CARVALHO, J. M. 1990. A formação das almas: o imaginário da República no Brasil. São Paulo: Companhia das Letras.

CHADAREVIAN, P. C. 2012. Raça, classe e revolução no Partido Comunista Brasileiro (1922-1964). Política E Sociedade, v. 11, n. 20, pp. 255-283.

CHILCOTE, R. 1982. Partido Comunista Brasileiro: conflito e integração 19221972. Rio de Janeiro: Graal.

COLETIVO Negro Minervino de Oliveira. [20-?]. O coletivo. Disponível em: <https://goo.gl/xST58b>. Acesso em: 15 ago. 2017.

COLUMNA Operaria. O Paiz, Rio de Janeiro, 29 dez. 1913, p. 5. (Centro dos Operários Marmoristas)

CONFEDERAÇÃO Geral do Trabalho do Brasil. [192-?]. Fundo Polícia Política, Setor Comunismo, notação 15, dossiê 4, folha 7. Rio de Janeiro: Aperj.

CONGRESSO operario nacional. O Jornal, Rio de Janeiro, $1^{\circ}$ maio 1929, p. 11. CONSELHO municipal. O Jornal, Rio de Janeiro, 10 out. 1929, p. 3. 
CONSULTANDO as forças da opinião nacional sobre a sucessão. Diário Carioca, Rio de Janeiro, 30 jan. 1929, p. 3.

DEL ROIO, M. 1990. A classe operária na revolução burguesa: a política de alianças do PCB (1928-1935). Rio de Janeiro: Oficina de Livros. 2007. A gênese do Partido Comunista (1919-29). In: FERREIRA, J. L.; REIS, D. A. (orgs.). A formação das tradições (1889-1945). Rio de Janeiro: Civilização Brasileira, 2007, pp. 223-248. (Coleção As Esquerdas no Brasil, v. 1).

DI CAVALCANTI, E. 1964. Reminiscências líricas de um perfeito carioca. Rio de Janeiro: Civilização Brasileira.

DIAS, E. 1977. História das lutas sociais no Brasil. 2. ed. São Paulo: Alfa-Omega.

DOIS ex-intendentes communistas presos porque tomaram parte num comicio communista. O Jornal, Rio de Janeiro, 8 nov. 1930, p. 8.

DROZ, J. H. 1979. Um enviado da IC à América Latina passa pelo Brasil (1929). In: PINHEIRO, P. S.; HALL, M. M. (orgs.). A classe operária no Brasil: documentos (1889-1930). v. 1: O movimento operário. São Paulo: Alfa-Omega, 1979, pp. 309-313.

DULLES, J. W. F. 1977. Anarquistas e comunistas no Brasil (1900-1935). 2. ed. Rio de Janeiro: Nova Fronteira.

ECOS e noticias. Jornal do Brasil, Rio de Janeiro, 16 maio 1930, p. 5.

EM POLVOROSA, o recinto, por causa dos communistas! Critica, Rio de Janeiro, 6 dez. 1929, p. 3.

ESTÁ definitivamente constituída a Liga Anti-Imperialista do Brasil.

Critica, Rio de Janeiro, 21 fev. 1929, p. 5.

FAUSTO, B. 1977. Trabalho urbano e conflito social (1890-1920). São Paulo: Difel. FOI dissolvido, a bala, o comicio de hontem do Bloco Operario e

Camponez. A Manhã, Rio de Janeiro, 8 nov. 1929, pp. 1 e 12.

FOI preso, novamente, o intendente Minervino de Oliveira. OJornal, Rio de Janeiro, 14 fev. 1930, p. 8.

FORAM presos, hontem, em Bangú, o intendente Minervino de Oliveira, o dr. Paulo de Lacerda e graphico Mario Grazzini. A Batalha, Rio de Janeiro, 13 fev. 1930, p. 3.

GOMES, A. M. C. 2005. A invenção do trabalhismo. 3. ed. Rio de Janeiro: FGV. GRAHAM, J. 2014. A virada antirracista do Partido Comunista do Brasil, a Frente Negra Brasileira e a Ação Integralista Brasileira na década de 1930. In: GOMES, F.; DOMINGUES, P. (orgs.). Políticas da raça: experiências e legados da abolição e da pós-emancipação no Brasil. São Paulo: Selo Negro, 2014, pp. 353-375. 
JAMES, C. L. R. 1985 [1938]. A history of negro revolt. 3. ed. London: Race Today.

KAREPOVS, D. 2006. A classe operária vai ao parlamento: o Bloco Operário e Camponês do Brasil (1924-1930). São Paulo: Alameda.

LACERDA, C. 2001. Rosas e pedras de meu caminho. Brasília: UnB.

LÊNIN, V. I. 1975 [1902]. Que fazer? Lisboa: Estampa.

LIMA, A. 1931. Da caserna ao cárcere. Rio de Janeiro: Typ. São Benedicto.

LIMA, A. S. 2015. Comunismo contra racismo: autodeterminação e vieses de integração de classe no Brasil e nos Estados Unidos (1919-1939). Tese de doutorado em História. São Paulo: FFLCH, USP.

LONER, B. A. 2015. A repressão na Primeira República e os militantes operários. In: MARQUES, A. J.; STAMPA, I. T. (orgs.). Arquivos e o direito à memória e à verdade no mundo dos trabalhadores. Rio de Janeiro: Arquivo Nacional; São Paulo: CUT, 2015, pp. 91-106.

MARAM, S. L. 1979. Anarquistas, imigrantes e o movimento operário brasileiro, 1890-1920. Rio de Janeiro: Paz e Terra.

MATTOS, H. 2012. A vida política. In: SCHWARCZ, L. M. (org.). História do Brasil nação: a abertura para o mundo 1889-1930. v. 3. São Paulo: Objetiva, 2012, pp. 85-131.

MATTOS, M. B. 2002. Trabalhadores e sindicatos no Brasil. Rio de Janeiro: Vício de Leitura.

MATTOS, M. B. et al. 2004. Trabalhadores em greve, polícia em guarda: greves e repressão policial na formação da classe trabalhadora carioca. Rio de Janeiro: Bom Texto.

MINERVINO de Oliveira. [192-?]. Fundo polícias políticas do Rio de Janeiro, Prontuário GB 15.652 e Prontuário RJ 3.913. Rio de Janeiro: Aperj.

MINERVINO de Oliveira, veterano líder operário, fala-nos sobre esse acontecimento histórico da vida nacional - Recordando lutas proletárias e o III Congresso do PCB. Imprensa Popular, Rio de Janeiro, 11 dez. 1954, p. 3.

MINERVINO também é candidato. Gazeta de Noticias, Rio de Janeiro, 8 nov. 1929 , p. 1.

MUNICIPIOS. Diário Nacional, São Paulo, 17 jan. 1930, p. 11. (De Ribeirão Preto)

NAZARETH, A. 1929. O maior propagandista do communismo. A Manhã, Rio de Janeiro, 8 nov. 1929, p. 3.

O COMICIO de hontem do Bloco Operario e Camponez. O Jornal, Rio de Janeiro, 8 nov. 1929a, p. 16.

O COMICIO do Bloco Operario e Camponez na tarde de hontem. Diário Carioca, Rio de Janeiro, 8 nov. 1929b, p. 3. 
O DIA policial. Correio da Manhã, Rio de Janeiro, 8 nov. 1929, p. 5.

O GOVERNO fluminense não quer opposição nas proximas eleições? Diário Carioca, Rio de Janeiro, 21 ago. 1929, p. 2.

O GRANDE prelio eleitoral de hontem. O Paiz, Rio de Janeiro, 2 mar. 1930 , p. 1.

O "LOCK-OUT" dos industriais marmoristas. A Razão, Rio de Janeiro, 3 jul. 1918, p. 7.

O PROLETARIADO do Brasil, pujante, coheso e disciplinado, viveu hontem um dos seus dias mais gloriosos. Critica, Rio de Janeiro, 2 maio 1929, pp. 1-2

O RECONHECIMENTO dos novos intendentes. A Manhã, Rio de Janeiro, 18 dez. 1928, p. 2.

O SR. MINERVINO de Oliveira preso pela policia de S. Paulo. O Jornal, Rio de Janeiro, 14 jan. 1930, p. 16.

OCTAVIO Brandão e Minervino de Oliveira são os candidatos do B.O.C. A Classe Operaria, Rio de Janeiro, 25 ago. 1928, pp. 1 e 4.

OLIVEIRA, T. B. 2009. Anarquismo, sindicatos e revolução no Brasil (19061936). Tese de doutorado em História. Niterói: ICHF, UFF.

OS “SALDOS” do governo Washington Luis. Correio da Manhã, Rio de Janeiro, 29 nov. 1930, p. 3.

OS COMMUNISTAS agem aqui e em Petropolis. Gazeta de Noticias, Rio de Janeiro, 22 jan. 1930, p. 8.

OS COMMUNISTAS em propaganda. Jornal do Brasil, Rio de Janeiro, 8 nov. 1929, p. 11.

OS OPERARIOS e a policia fluminense. OJornal, Rio de Janeiro, 21 ago. 1929 , p. 5.

PARECE que o sr. Minervino de Oliveira, não tendo chegado a Santos, foi detido em S. Paulo - Cerca de 50 operarios presos. A Batalha, Rio de Janeiro, 26 fev. 1930, p. 8.

PATRÕES e operários num ambiente de cordialidade. Tribuna Popular, Rio de Janeiro, 5 jul. 1945, p. 2.

PEREIRA, A. 1976. Formação do PCB (1922-1928). Lisboa: Prelo.

PINHEIRO, P. S. 1991. Estratégias da ilusão: a revolução mundial e o Brasil, 1922-1935. São Paulo: Companhia das Letras.

PINHEIRO, P. S.; HALL, M. M. (orgs.). 1979. A classe operária no Brasil: Documentos (1889-1930). v. 1: O movimento operário. São Paulo: Alfa Ômega.

PORQUE foi anunciada a visita de Sr. Minervino de Oliveira a Santos.

Diário Nacional, São Paulo, 25 dez. 1929, p. 2. 
PREPARANDO a 'Presidência Minervino'. Uma diligência policial agitada na estação B. Ribeiro. Diário da Noite, Rio de Janeiro, 22 fev. 1930, p. 2.

PRESOS em Nictheroy quando falavam num comicio, os intendentes operarios Minervino de Oliveira e Octavio Brandão e a esposa deste ultimo. OJornal, Rio de Janeiro, 8 out. 1929, p. 18.

PROTESTAE contra a reacção, votando nos candidatos do Bloco Operario e Camponez. A Batalha, Rio de Janeiro, $1^{\circ}$ mar. 1930, p. 3.

PROTESTAI contra a reacção votando nos candidatos do Bloco Operario e Camponez. O Jornal, Rio de Janeiro, $1^{\circ}$ mar. 1930, p. 6.

PROTESTO de solidariedade aos graphicos de S. Paulo. OJornal, Rio de Janeiro, 2 abr. 1929, p. 3.

QUE teria feito a policia com o sr. João Freire de Oliveira? Diário Nacional, São Paulo, 8 mar. 1930, p. 3.

REALIZA-SE hoje o $1^{\circ}$ Congresso Nacional do Bloco Operario e Camponez. O Jornal, Rio de Janeiro, 6 nov. 1929, p. 5.

REGO, O. B. 1993. Octávio Brandão (depoimento, 1977). Rio de Janeiro: CPDOC.

REPRIMINDO a propaganda comunista. Gazeta de Noticias, Rio de Janeiro, 11 dez. 1929 , p. 8.

50 RODRIGUES, L. M. 1981. O PCB: os dirigentes e a organização. In: FAUSTO, B.; HOLANDA, S. B. (orgs.). O Brasil republicano: sociedade e política (1930-1964). t. III, v. 3. São Paulo: Difel, 1981, pp. 431-530. (Coleção História Geral da Civilização Brasileira).

ROSA, L. R. O. 1997. Comunistas em Ribeirão Preto (1922-1947). Dissertação de mestrado em História. Franca: Universidade Estadual Paulista.

SANTOS, C. D. F. 1948. A marcha vermelha. São Paulo: Saraiva.

SEGATTO, J. A. 1989. Breve história do PCB. Rio de Janeiro: Oficina de Livros.

SILVA, A. J. 2002. Comunistas e trotskistas: a crítica operária à Revolução de 1930. Curitiba: Moinho do Verbo.

SILVA, T. L. 2013. Entre a ação legislativa e o constrangimento político: o Conselho Municipal do Distrito Federal (1921-1930). Dissertação de mestrado em História, Política e Bens Culturais. Rio de Janeiro: CPDOC, FGV.

SOUZA, P. M. 1955. Um grande manancial de ricas experiências e ensinamentos para a luta do proletariado. Imprensa Popular, Rio de Janeiro, 24 jul. 1955 , p. 8.

TERMINOU a gréva dos marmoristas. A Razão, Rio de Janeiro, 10 jul. 1918, p. 2. 
TERMINOU a gréve dos marmoristas. A Razão, Rio de Janeiro, 27 jun. 1919 , p. 4.

UM DESAFIO á lei, á sociedade e aos poderes publicos! A Noite, Rio de Janeiro, 22 jan. 1930.

UMA REUNIÃO de jornalistas, hontem, no gabinete do chefe de policia. O Jornal, Rio de Janeiro, 7 fev. 1931, p. 5.

VIANNA, M. A. G. 2007. O PCB: 1929-43. In: FERREIRA, J. L.; REIS, D. A. (orgs.). A formação das tradições (1889-1945). Rio de Janeiro: Civilização Brasileira, 2007, pp. 331-363. (Coleção As Esquerdas no Brasil, v. 1).

VISCARDI, C. M. R. 2012. O teatro das oligarquias: uma revisão da "política do café com leite". 2. ed. Belo Horizonte: Fino Traço.

ZAIDAN FILHO, M. 1989. Comunistas em céu aberto, 1922-1930. Rio de Janeiro: Oficina de Livros. 


\section{MINERVINO DE OLIVEIRA: UM NEGRO COMUNISTA DISPUTA A PRESIDÊNCIA DO BRASIL}

\section{PETRÔNIO DOMINGUES}

Resumo: Minervino de Oliveira - um afro-brasileiro que nasceu no Rio de Janeiro apenas três anos após a abolição da escravatura - foi o candidato escolhido pelo Partido Comunista do Brasil para concorrer à presidência da República em 1929. Apesar de ter recebido uma votação pouco expressiva nas eleições, sua campanha não ficou destituída de importância histórica, já que foi o primeiro candidato afro-brasileiro, operário e comunista a disputar o cargo mais importante da nação. A proposta deste artigo é apresentar breves notas acerca desse personagem e, especialmente, reconstituir aspectos de sua carreira política e campanha eleitoral do final de 1929 ao primeiro trimestre de 1930.

Palavras-chave: Afro-brasileiro; Raça; Comunismo.

\section{MINERVINO DE OLIVEIRA: A BLACK COMMUNIST RUNS FOR BRAZILIAN PRESIDENCY}

Abstract: Minervino de Oliveira - an Afro-Brazilian who was born in Rio de Janeiro three years after the slavery abolition - was the candidate chosen by the Brazilian Communist Party to run for presidency in 1929. Although he did not get an expressive number of votes in the poll, his campaign did not lose its historical importance, since he was the first Afro-Brazilian, factory worker and communist candidate to run for the most important position in the nation. The aim of this article is to present some excerpts about this character and to rebuild aspects of his political career and election campaign from late 1929 to the first three months of 1930.

Keywords: Afro-Brazilian; Race; Communism.

Recebido: 23/12/2016 Aprovado: 04/08/2017 